\title{
Sustainable Economic Planning and Distribution of Mineral Rents in Local Communities: Evidence from Ghana
}

\author{
George Ayuune Akeliwira ${ }^{1 *} \quad$ Bernard Anaba ${ }^{2}$ \\ 1.Centre for Empirical Research in Economics and Behavioral Sciences, University of Erfurt. \\ Donaustrasse 34, 99089 Erfurt, Germany \\ 2.Integrated Social Development Centre (ISODEC), Post Office Box MP 2989 Mamprobi, Accra -Ghana \\ *E-mail of corresponding author: george.akeliwira.01@uni-erfurt.de or georgeakeliwira@gmail.com
}

\begin{abstract}
Mineral-endowed Districts are among the most underdeveloped communities in Ghana, partly because Districts are structurally constrained from recouping socio-economic cost directly from mines. In 2016, Parliament passed the Minerals Development Fund Act, a tool to address the socio-economic development challenges in mining affected communities. The study examines the capacity of local government structures in utilizing the Minerals Development Fund and other mineral royalties to promote inclusive and sustainable economic development. Through interviews with 300 respondents aged between 15 and 65 and drawn from communities with mining operations in Prestea-Huni Valley and Wassa East Districts, the study finds that there are existential capacity gaps in development planning and community participation in the management of mineral resources in communities within the periphery of extractive activities.
\end{abstract}

Keywords: Mining, Planning, Participatory, Communities, Development, Mineral Rents

DOI: $10.7176 / \mathrm{JESD} / 13-2-01$

Publication date: January $31^{\text {st }} 2022$

\section{Introduction}

According to Akabzaa and Darimani in (Azumah et al. 2020), Ghana's mining industry was very vibrant during the pre-independence period, thus Ghana accounted for 35\% of total gold output globally between 1493 and 1600 . Unfortunately, this growth output witnessed a consistent decline over subsequent years in the post-independence period, which was marked by state ownership of mineral resources. The period up to 1986 was when the industry witnessed real deterioration in growth. To arrest the downward spiral in growth in the mining sector in particular and the overall economy, the government of Ghana, under the instigation of and with support from the Bretton Woods institutions, embarked on an Economic Recovery Programme (ERP) in 1983. The objective of ERP was to arrest the near collapse of the Ghanaian economy and to boost the major export sectors that were in a decline because of lack of investment for decades ${ }^{1}$. The main objective of the mining sector programme was to halt the decline in and stabilize mineral production, through short time non-monetary, monetary and economic measures. This was to be done through rehabilitation of existing mines by injecting financial and technical assistance from multinational institutions, divestiture and liberation of the sector to promote an enabling environment for private sector investment (Songsore, 2003).

In addition, the programme also eliminated restrictions on imports and foreign exchange transactions, which were largely responsible for the decline of the mining sector and larger economy. The investment in the sector has contributed to Ghana's current position as number seven on the global league of major gold producers and the first largest gold producer in Africa (Gold Council, 2019). Overall, the extractive sector contributes significantly to the Ghanaian economy in terms of export values and around $60 \%$ of export revenues come from gold mining and petroleum exploitation (IMF, 2017). Furthermore, available data from the Bank of Ghana shows that in the year 2019 , the total merchandise export earnings from minerals was US\$15, 667.53 million compared to US\$ 14,942 in 2018. Thus, the contribution of minerals to foreign exchange earnings for the year was $42.63 \%$, and that represents a $15.95 \%$ increase in the value of mineral export over the period of 2018 to 2019. As shown in Figure1 below, gold and other minerals remain the leading export commodity in Ghana ahead of crude oil, cocoa and timber.

The 2019 data of the export values of Ghana's major export commodities is a confirmation that the mining sector remains the lead foreign exchange earner for the country, a feat that could be attributed to the investment in the mining sector under Structural Adjustment and Economic Recovery Programs in the 1980s.

\footnotetext{
Ghana, Structural Adjustment for Growth (English).https://documents.worldbank.org/en/publication/documentsreports/documentdetail/496401468249898352/ghana-structural-adjustment-for-growth.
} 
Figure1. Merchandise Export of Major Commodities for the year 2019

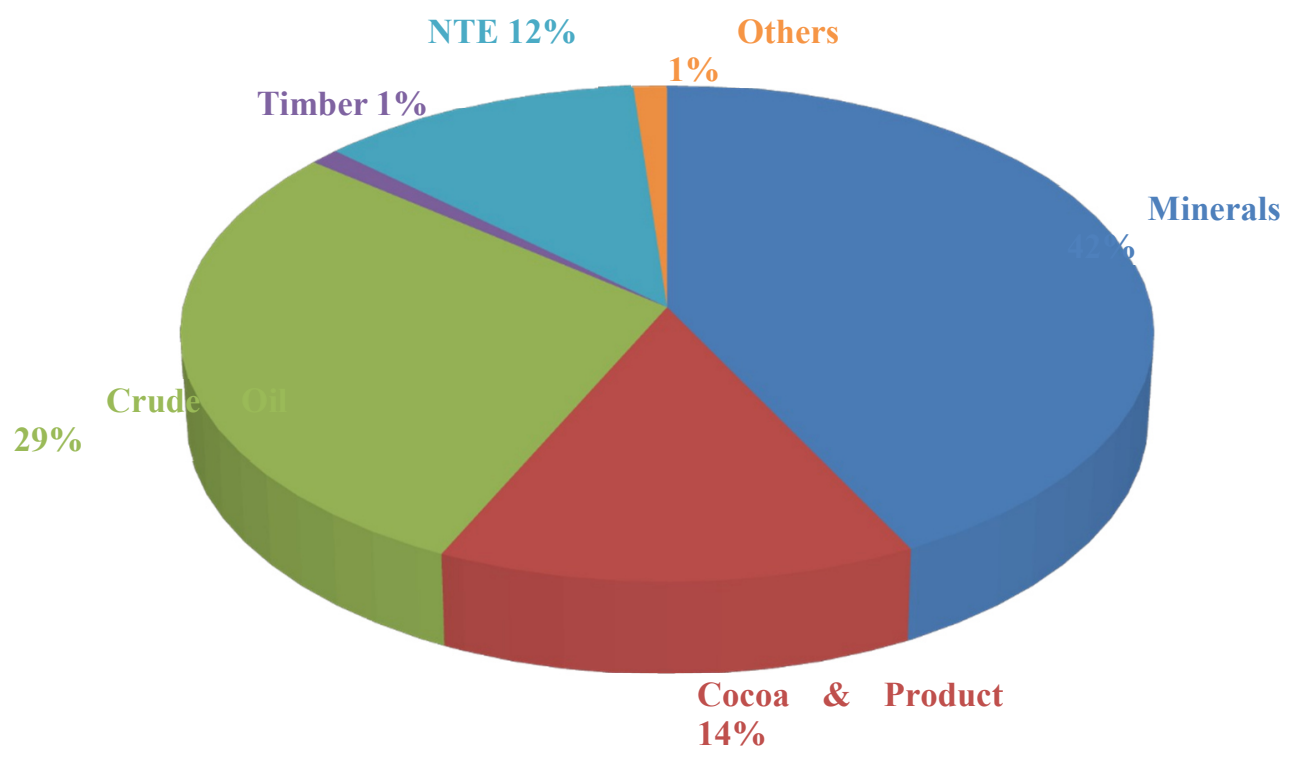

Source: Bank of Ghana (2019)

The micro impacts of the current boom in the mining sector in terms of employment generation cannot be understated. Whereas it is estimated that about 22,000 are employed in the large-scale mining sector, over a million and more are economically engaged in the small-scale sector. In 2018 alone, the small-scale sector contributed about $43 \%$ of the total gold produced (Minerals Commission, 2019). Mcquilken and Hilson (2016) estimated that, mining and activities in the mining value chain cumulatively provide a means of livelihood for more than five million people, either directly or indirectly in Ghana.

The growth in gold output from the small-scale sub-sector is likely to translate into increase in household income, it also poses major challenges for the country in terms of exports of the country's gold output due to weak enforcement of laws and controls as the sector's gold output is a combination of legal and illegal production (illegal gold trade). Since the commencement of the reforms, there has been significant investment flows into the sector with regards to new mines and mineral properties at mine development and advance exploration stage, especially in the gold sector. The mining industry, especially the gold sector, is arguably the backbone of the economy in terms of revenue generation. Save for the years 2014 and 2015 that recorded decreases mainly due to the global decline in gold prices, the sector has been very consistent and on a higher trajectory in terms of its contribution to domestic revenue, as evidenced in the revenue trend from 2004 to 2019 in figure 2 below.

Figure 2. Revenue trend for Gold (US Dollars), 2004 - 2019.

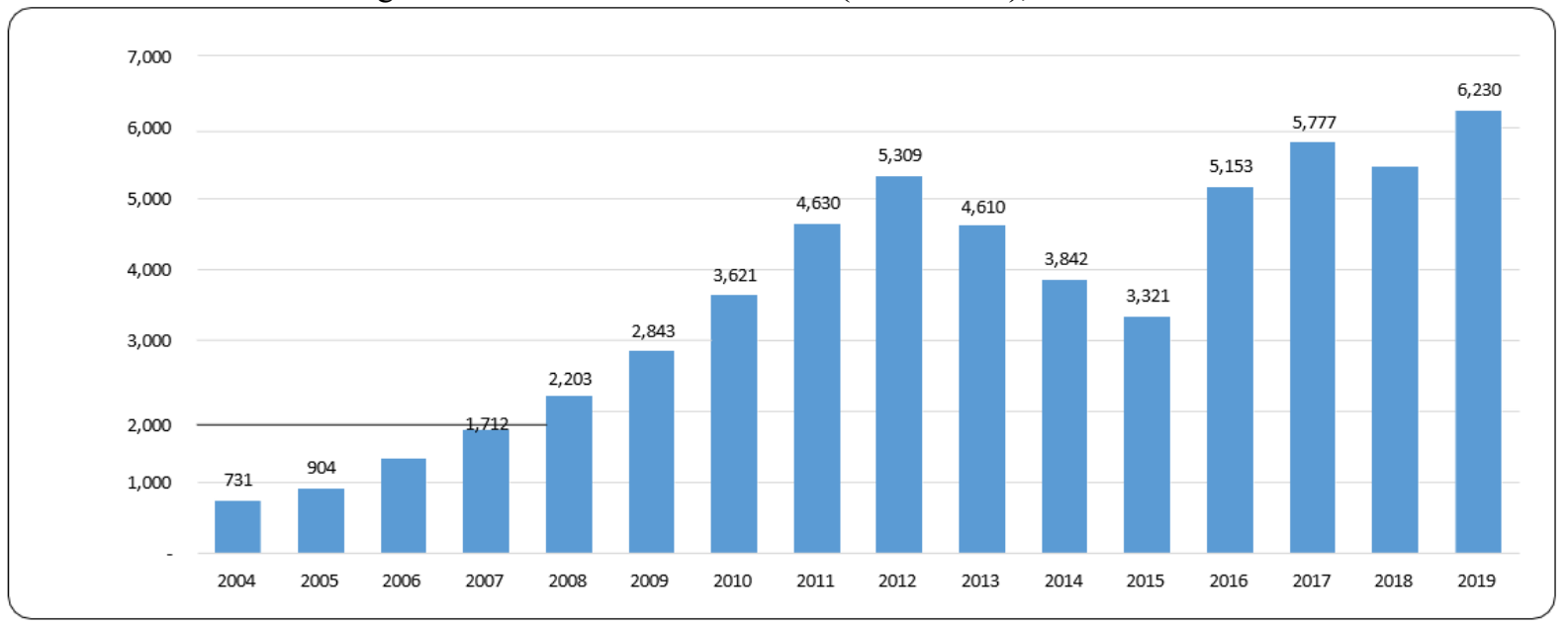

Source: Bank of Ghana (2019)

The mining sector has not only become an important destination for foreign direct investment, but also a 
leading sector in relation to domestic revenue mobilization, see (table 1). Critical to the progressive growth and boom in the mining sector was as indicated earlier, the liberation of the economy and the divestiture of most of the then moribund and mismanaged state owned enterprises (SOEs). The divestiture of these SOEs, which began in the 1980s, was inspired by the Bretton Woods institutions and the donor community as part of development assistance conditionality. Thus, the Structural Adjustment Program (SAP) and the Economic Recovery Program (ERP) opened the sector up for private sector participation and this brought in more efficiency in management, new technologies and the discovery and development of new mine sites.

Based on the investments and growth in the sector in recent years, many are of the view that the mining industry in Ghana has the capacity to generate substantial revenues in the form of taxes to stimulate economic growth and improve living conditions of people living in mining affected communities. Indeed, the impetus and strong will to carry through these profound reforms is premised on the conviction of Ghana officialdom that the mining sector has a strong potential to accelerate national development and reduce poverty, particularly in communities within the periphery of mining projects, Akabzaa in (Campbell, 2009).

However, there are a growing number of skeptics who do not view the industry in this direction. According to this school of thought, irrespective of the commendable trends and the investment boom in the sector, it has not led to significant integrated development or an improvement on the socioeconomic conditions of people living in mining affected towns. Example, Aryeetey et al. (2004), intimated that the performance of the sector as the leading destination for FDI, and dominant gross foreign exchange earner has not reflected visibly on the performance of the national economy.

Table 1: Contributions to Direct Domestic Revenue by Sector $(2015$ - 2019)

\begin{tabular}{|c|c|c|c|c|c|c|c|c|c|c|}
\hline \multirow{2}{*}{ SECTOR } & \multicolumn{2}{|c|}{ CONTRIBUTION 2015} & \multicolumn{2}{|c|}{ CONTRIBUTION 2016} & \multicolumn{2}{|c|}{ CONTRIBUTION 2017} & \multicolumn{2}{|c|}{ CONTRIBUTION 2018} & \multicolumn{2}{|c|}{ CONTRIBUTION 2019} \\
\hline & GHé & $\begin{array}{l}\% \text { to } \\
\text { total } \\
\text { Ghana }\end{array}$ & $\mathbf{G H} \dot{c}$ & $\begin{array}{l}\% \text { to } \\
\text { total } \\
\text { Ghana }\end{array}$ & $\mathbf{G H e}$ & $\begin{array}{l}\% \text { to } \\
\text { total } \\
\text { Ghana }\end{array}$ & GHé & $\begin{array}{l}\% \text { to } \\
\text { total } \\
\text { Ghana }\end{array}$ & GHé & $\begin{array}{l}\% \text { to } \\
\text { total } \\
\text { Ghana }\end{array}$ \\
\hline $\begin{array}{l}\text { Agriculture, } \\
\text { hunting } \\
\text { and forestry \& } \\
\text { fishing }\end{array}$ & $2,438,273.20$ & 0.18 & $66,662,001.52$ & 0.63 & $68,385,621.25$ & 0.52 & $96,028,954.79$ & 0.58 & $118,896,631.17$ & 0.54 \\
\hline $\begin{array}{l}\text { Mining and } \\
\text { Quarrying }\end{array}$ & $196,693,138.51$ & 14.62 & $1,648,183,048.75$ & 15.8 & $2,160,742,773.16$ & 16.30 & $2,362,194,425.41$ & 14.20 & $4,013,367,649.79$ & 18.38 \\
\hline $\begin{array}{l}\text { Mining Support } \\
\text { Serv. } \\
\text { (Petro. \& Gas) }\end{array}$ & $\mathrm{n} / \mathrm{a}$ & $\mathrm{n} / \mathrm{a}$ & $\mathrm{n} / \mathrm{a}$ & $\mathrm{n} / \mathrm{a}$ & $728,352,890.07$ & 5.49 & $1,211,106,732.07$ & 7.28 & $1,468,055,752.12$ & 6.72 \\
\hline Manufacturing & $101,724,642.40$ & 7.56 & $634,502,394.33$ & 6.08 & $682,111,457.03$ & 5.15 & $1,270,945,879.35$ & 7.64 & $1,043,075,349.84$ & 4.78 \\
\hline $\begin{array}{l}\text { *Electric } \text { Gas, } \\
\text { Steam and } \\
\text { Air Con supply }\end{array}$ & $8,136,391.96$ & 0.60 & $125,162,980.26$ & 1.2 & $287,501,310.08$ & 2.17 & $254,148,392.44$ & 1.53 & $423,484,584.78$ & 1.94 \\
\hline $\begin{array}{l}\text { *Water Supply, } \\
\text { Sew. \& } \\
\text { Waste } \\
\text { Management }\end{array}$ & $2,546,049.38$ & 0.19 & $38,877,141.53$ & 0.37 & $40,142,942.48$ & 0.30 & $55,665,022.16$ & 0.33 & $58,959,659.33$ & 0.27 \\
\hline $\begin{array}{l}\text { Construction and } \\
\text { Construction } \\
\text { equipment }\end{array}$ & $32,053,411.51$ & 2.38 & $294,236,447.66$ & 2.82 & $412,622,696.41$ & 3.11 & $519,767,954.12$ & 3.12 & $450,461,547.36$ & 2.06 \\
\hline $\begin{array}{l}\text { Wholesale and } \\
\text { retail }\end{array}$ & $78,536,941.79$ & 5.84 & $1,023,994,697.01$ & 9.82 & $2,049,566,743.22$ & 15.46 & $2,698,644,063.96$ & 16.22 & $1,367,217,760.00$ & 6.26 \\
\hline $\begin{array}{l}\text { Hotel and } \\
\text { Restaurant / } \\
\text { Accommodation } \\
\text { and } \\
\text { Food service }\end{array}$ & $17,865,393.41$ & 1.33 & $77,577,663.24$ & 0.74 & $86,162,093.97$ & 0.65 & $95,396,136.24$ & 0.57 & $170,005,389.53$ & 0.78 \\
\hline $\begin{array}{l}\text { Transport and } \\
\text { Storage }\end{array}$ & $61,967,389.04$ & 4.60 & $469,746,023.25$ & 4.5 & $611,757,246.46$ & 4.62 & $862,964,489.72$ & 5.19 & $683,023,496.11$ & 3.13 \\
\hline Communication & $113,313,636.11$ & 8.42 & $567,151,025.23$ & 5.44 & $760,103,269.09$ & 5.73 & $638,739,883.83$ & 3.84 & $1,261,836,955.10$ & 5.78 \\
\hline $\begin{array}{l}\text { Fin. } \\
\text { Intermediation }\end{array}$ & $229,413,663.07$ & 17.05 & $1,578,122,696.68$ & 15.13 & $2,147,094,825.85$ & 16.20 & $2,054,095,243.47$ & 12.34 & $4,786,721,894.28$ & 21.92 \\
\hline $\begin{array}{l}\text { Real Estate and } \\
\text { renting } \\
\text { activities }\end{array}$ & $12,180,363.02$ & 0.91 & $105,080,925.70$ & 1 & $132,338,232.41$ & 1.00 & $145,785,154.42$ & 0.88 & $190,643,489.58$ & 0.87 \\
\hline
\end{tabular}

Source: Bank of Ghana (2019)

\section{Literature Review}

The study examines local institutional capacity gaps in sustainable economic development planning with integration of mineral resources. It addresses the following questions:

- What pressing development challenges confront communities affected by gold mining?

- How do local authorities integrate extractive activities into their medium to long-term development plans?

- What constraints hamper collaborations among key actors in the management of mineral resources?

To provide a context for explaining these pertinent issues outlined above, and to answer the central question(s) underpinning the study we examined some of the theoretical models concerning mineral resources and sustainable economic development nexus.

\subsection{Fiscal Regime and Microeconomics}

Mackenzie (1987) defined mineral economics as "the application of economics in the study of all aspects of the 
mineral sector". As an economic field of study, mineral economics is defined as the academic discipline that conducts research and education on economic and policy issues associated with the discovery, extraction, processing, use, recycling, and disposal of mineral commodities. Being at the beginning of the value chain, minerals have the capacity to affect the overall economy in a big way (Subhash and Indran, 2016).

Economic factors controlling mineral production from the supply side largely include engineering and environmental costs related to extraction and processing and those on the demand side, which include commodity prices, taxation, land tenure and other legal policies of the host government. In view of this, Kesler et al. (2015) opined that although the balance among these factors can be considered from many economic perspectives, it is impossible to avoid the fact that the cost of producing a mineral must be borne by the deposit from which it comes, in this case through mineral royalties and or mineral tax policy in general. Based on this background, social science research on the mining sector has shifted from the traditional research streams such as industrialization and growth, colonialism, technological and the resource curse to the new streams on social, environmental and economic sustainability (the social license to operate, corporate social responsibility and environmental impacts), (Karakaya and Nuur, 2018).

An extensive work by Sexton (2020), on claims and activism regarding mining externalities and benefits sharing in Peru, found that the Peruvian government developed a framework for environmental regulation and a tax revenue sharing scheme that redistributes money from mining duties to the areas where extraction takes place. In this regard, the central Ministry of Finance's oversight role is restricted to procurement and accounting concerns, rather than the distribution of mineral rents or political accountability concerns.

Among the benefits of decentralizing the management of mining revenues is that it helps for proper targeting of communities and people directly affected by mining externalities and how those externalities can be ameliorated through fiscal policies or royalties. As explained by Haldar (2018), a mineral fiscal policy encompasses issues or mechanisms related to application and registration fees, royalty, income tax, compensation to land owners, rehabilitation cost, and annual dead rent applicable to holders of mineral exploration and mining rights.

Royalties are a traditional means by which the ultimate owners of exhaustible resources attempt to capture resource rents (Ergars and Pincus, 2014). In most mineral-rich economies, royalties are exclusively state or provincial earnings and constitute a significant revenue source for states and therefore, placing them in a proper position can internalize or arrest market failures inherent in mining operations at the community-level (Haldar, 2018).

Previous studies have confirmed the assertion that the resource curse hypothesis is not generic. Example, a study by Hajkowicz et al. (2011) on quality of life indicators such as employment, household income, access to communication services and among others at the community-level and the gross value of minerals production found no evidence of systematic negative associations between quality of life and the gross value of minerals production. While the study did not establish any evidence of negative externalities, which could be a scale issue, nonetheless the study asserted that the types of policy mechanisms and mining taxation put in place by governments go a long way to mitigate or avoid negative impacts of mining on local livelihoods.

Work by de Souza et al. (2018) on mining royalties and legal regimes in Queensland local government areas in Australia concluded that, mining royalties are accrued to state governments and not to Local Government Areas (LGAs) where mining occurs, despite the fact that mining imposes heavy localized costs especially on local public infrastructure. There is thus a disjunction between the spatial incidence of the benefits and costs of mining, sometimes termed as the 'resource-return mismatch', especially since mining predominantly takes place in regional, rural and remote areas whereas the bulk of mining royalties are expended in metropolitan centers. As a result, there is a mismatch between the costs and revenues associated with mining at local levels, (Blackwell et al. 2018).

Further, a study by Darcy Tetreault (2020), on localized rent-redistribution programs implemented alongside reforms to open the mining sector to private and foreign investment in an effort to accelerate extraction rates and internalize mining externalities reveals that, while these programs seek to compensate directly affected populations, they do not address the most fundamental demand of most community-based resistance movements. This is because populations impacted by mining operations feel that their right to decide on projects are either limited or the channels do not exist.

\subsubsection{The Paradox of Plenty}

The 'resource curse' hypothesis, otherwise called the 'paradox of plenty' explains the adverse effects of a country's natural resource wealth on its economic, social, or political well-being, (Ross, 2015). In other words, 'resource curse' or 'paradox of plenty' refers to a situation whereby a country has an export-driven natural resources sector that generates large revenues for the government but leads paradoxically to economic stagnation and political instability. ${ }^{1}$ The concept thus, explains the inverse association between development and natural resource

\footnotetext{
${ }^{1}$ Overseas Development Institute (2006); Catholic Relief Services (2003). Access from: African Development Report 2007 - Chapter IV -
} Africa's Natural Resources: The Paradox of Plenty (afdb.org) 
abundance.

Chuhan-Pole et al. (2017) have identified three main channels through which the abundance of mineral resources affects local areas; first, the market mechanism, which refers to the impact on demand for jobs or other local inputs and their multiplier effects on non-mining sectors through backward and forward linkages or other spillovers. Second, the environmental channel, which outlines the impact that pollution and natural resources use during mining activities, may have on human or animal health, environmental quality, and endowments of natural resources or access to them. The final channel is mainly represented by an increase in fiscal revenues, whose positive or negative effects are usually influenced by institutional quality such as corruption and mismanagement.

In all these, the most glaring and devastating of them is the environmental channel. Thus, the permanent damage to the ecosystem and other livelihood foundations from mining operations in local communities need not be overemphasized. Example, a study by Aragon and Rud in Ghana, have shown that air pollution around industrial gold mining has been linked to increased cough incidence (Lilford and Guj, 2020). Mining operations often require the intensive use of water resources and this can create heavy environmental externalities, including soil erosion, and contamination, air and water pollution from acid mine drainage, to leakage of chemicals and sedimentation (Antoci et al. 2019).

As succinctly explained by Akabzaa in (Campbell, 2009), "the increased expatriate staff quotas in the mines and the negative environmental and social impacts of mining activities on local communities have contributed to dwarf the contribution of the sector to national development and poverty alleviation". Thus, structural problems coupled with illicit activities in the sector deprive mineral-endowed developing countries from deriving maximum benefits from the sector. These impacts spur community actors to demand more diligence and attention from mining companies to ensure they keep damage to a minimum or, in some cases, completely reconsider (Poelzer et al. 2021).

The fiscal aspects, espoused by Chuhan-Pole et al. (2017), whose positive or negative effects are usually influenced by institutional quality through mismanagement and corruption, elucidates the fact that local communities rarely benefit from tax revenue accruing from mining operations in their communities. Thus, the ability of the mining industry to contribute meaningfully to poverty reduction at the community level will depend largely on the share of mining revenues accruing to local communities and the prudent management of local benefits. However, this is not the case in many emerging economies as taxes from extractives are collected and disbursed by central governments without commitment to invest back in communities where the resources are extracted. In other instances, communities affected by mineral exploitation do not even know their share of the resource boom in terms of tax revenues (Lujala and Narh, 2019).

While it is argued that mining, as an activity and industry, usually leads to negative environmental and social outcomes for local communities with little economic compensation, it is suggested that the fiscal framework and institutional design matter in relation to the magnitude of negative outcomes (Poelzer and Jagers, 2021).

\section{Brief Note on Methodology}

To investigate the nexus between gold mining and sustainable economic development, face-to-face interviews were conducted from 10 June 2017 to 30 June 2017 with local government heads in the two study districts, youth and women groups, non-partisan civil society groups active in the extractive sector as well as traditional and religious leaders. Given the saliency of the issue to be investigated and in order to accommodate diverse elements involved in the sample population, a sample size of 300 respondents across the two study Districts was considered appropriate for the study. In particular, it ensured a gender-balanced ratio in the choice and distribution of the unstructured questions for the respondents. The open-ended questions were useful to the study as a whole, as it allowed the research team to gain a better understanding of the stakeholders targeted and built rapports, which were useful for follow-ups.

Of the 300 respondents, 225 had formal education: 64 had basic education: 50 secondary education and 41 tertiary education. Only 87 of the respondents had no formal education.

The study also conducted focused group discussions with Community Based Organizations (CBOs), youth and women groups on their experiences in relation to the questions of participation within the local government system and their capacity to engage with other stakeholders. The FGs were also useful in eliciting their experiences and ideas about the distribution of mining benefits in the study Districts. The FG method was helpful on these issues as it stimulated dialogue and generated very interesting perspectives from the participants. The moderators had the opportunity to probe for details where necessary.

In all, six FG discussions were held in each District bringing all to a total of twelve for the two Districts. Four groups comprising a panel of youth, another four comprising women, two groups for CBOs and two for Assembly representatives. Each group was composed of at least seven individuals and not more than twelve persons. As far as possible, we made sure that members within a group were unfamiliar with each other and had similar characteristics. Level of education was a distinctive recruitment criteria used for the youth groups while occupation type was used for the women groups. 


\subsection{Questions}

The following questions were asked;

1. What is your understanding of participatory sustainable economic development planning?

2. How can the capacity of key actors in the management of mineral resources be strengthened?

3. How often do communities participate in issues regarding the management of mineral resources?

4. What are the key obstacles constraining women and youth participation in extractive governance?

5. How can local governments mainstream gender equality and youth issues in the extractive sector?

6. How can collaboration among key actors in the extractive sector be improved?

\subsubsection{Mode of Analysis}

Data collection instruments were systematically structured into specific thematic areas to ensure comprehensive coverage of specific issues and to facilitate efficient, effective and structured data capture, analysis and presentation. The interviews conducted were analyzed with a thematic focus (thematic approach). Excel spreadsheets were used for the analysis. The various responses to specific questions were entered into separate spreadsheets designed for each question. The responses were numbered, then coded and analyzed for broad thematic issues. The output of this process resulted in a data set that responded to the objectives of the study as input into drafting of the findings and drawing of conclusions.

\section{Political Administration of Wassa East}

Under Section 10 of the Local Government Act, 1993 (Act 462), the District Assembly is the highest political authority in the District and constitutionally empowered to oversee the overall development of the District as stated in Section two of the National Development Planning Systems Act (Act 480) ${ }^{1}$. There is a District Chief Executive, functions both as a political and administrative leader. According to Ghana Statistical Service, the District has four Area councils, which include Ekutuase, Daboase, Atieku and Enyinabrim. The District Coordinating Director is the administrative head while the Presiding Member is in charge of Assembly Proceedings. In all, the Assembly has 32 members, which are made up of 21 elected and 11 government appointees.

\subsection{Soils, Geology and Minerals}

There are four main categories of rock and soil types, which underlie the District. They include Birimian, Cape Coast granite and Tarkwaian. More than half of the soil consists of Cape Coast granite soils. Existing underground rocks in certain communities hinder the drilling of water facilities. The District has large deposits of gold and traces hence the upsurge of mining activities, which has resulted in the pollution of water resources in the District.

\subsubsection{Political Administration of Prestea-Huni Valley}

Prestea Huni-Valley District (PHD) is a one-constituency District made up of 32 electoral areas, an urban council and 6 area councils with 32 unit committees. The seven urban/area councils are Prestea, Huni-Valley, Beppoh, Awudua, Bogoso, Bondaye and Aboso area councils. There are 47 Assembly members made up of 32 elected and 14 government appointees including the District Chief Executive (DCE) \& the Member of Parliament (MP) who is an Ex-officio member. The Assembly is presided over by a Presiding Member who is elected from among the Assembly members by at least a two-thirds majority. The political and executive head of administration is the District Chief Executive (DCE). The Assembly performs its work through the Executive Committee, which is the highest committee of the Assembly and a network of sub-committees including the executive committee, which is chaired by the DCE, (Ahwoi, 2010).

\subsection{Economic Structure}

The economy of the District is mainly agrarian and it engages almost half of the population (45.2\%). This shows that agriculture continues to be the backbone of the District economy. There are other economic activities outside the agricultural sector especially in mining. Major companies in the District are Abosso Goldfields, Golden Star Resources, Bogoso/ Prestea Ltd, Prestea Sankofa Gold Ltd, New Century Mines (Prestea), Tarkwa Goldfields and AngloGold Ashanti Ltd².

\section{Findings}

\subsection{Participation in Local Governance Process}

Among the first questions in the survey was whether communities do actively participate in deliberations in relation to the governance process and issues of development in general in the District. This was necessary to

\footnotetext{
${ }^{1}$ An Act to establish and regulate the local government system in accordance with the Constitution and to provide for related matters. The Act makes provision for the administration of Districts, an area under a District Assembly, a municipality or metropolis. https://www.ecolex.org/details/legislation/local-government-act-1993-no-462-lex-faoc091927/

${ }^{2}$ The District Analytical Report for the Prestea/Huni Valley District is one of the 216 District census reports aimed at making data available to planners and decision makers at the district level. In addition to presenting the district profile, the report discusses the social and economic dimensions of demographic variables and their implications for policy formulation, planning and interventions.
} 
ascertain whether communities have a voice with respect to issues of social and economic developments that occur in their communities. It was established from the study that members of the community did not see themselves as part of the governance process in the Districts and as such, did not have the capacity or ability to influence the actions and directions of the Assemblies. This revelation is not too surprising as the topmost local government official (District Chief Executive) continues to be appointed by the President. In other words, the President appoints heads of decentralized government institutions. Though this requires an endorsement by elected and appointed Assembly representatives, the Government of the day succeeds in having its way through, using both formal and informal networks.

In this case, heads of District Assemblies are accountable to the appointing authority thus, the President who is at the top and not the people they preside over. This situation partly informs the feeling of powerlessness by communities when it comes to decisions and choices on expenditures and distribution of mineral resources for development priorities at local government level. Further, because communities are detached from governance and development planning in the Districts, most people had a challenge even understanding the mandate of the District Assemblies, even when we explained both in English and in Twi (native) language. They therefore used 'Assemblyman' interchangeably with District Assembly. This was mostly the case for communities far away from District capitals. Communities that host District capitals referred to the local government as 'Assembly' and seem to know some of the responsibilities expected of them.

\subsubsection{Mining and Local Development Planning}

The study sought to find out from the Assemblies if they integrate extractive activities in their development plans, considering the fact that these Districts host many of the mining companies in the country. The study discovered that development planning in the two mining Districts are hinged largely upon what they can take hold of and what is available to them. As a result, it is extremely difficult for the Assemblies to develop medium to long-term development plans. They could only come up with development plans based on the resources available to them at a particular point in time. Moreover, it was also realized that most of the mining companies in the Districts have their own initiatives on how to share benefits with communities. Among them being the provision of education scholarships to few brilliant but needy students.

As a result, the Assemblies do not have much control over the mining companies on the choice of community development projects or corporate social responsibility programs apart from the taxes and royalties received by the central government. The study further discovered that there are no formal processes of engaging mining companies operating in the Districts by the Assemblies. What pertains is that the extractive companies meet members of the community and inform them generally about their plans for the development of their host communities, which are mostly infrastructural projects without much consultation with beneficiary communities. This scenario does not only affect medium to long-term development plans in these mineral-based Districts, but also an affront to the Local Government Act 462, 1993 (102b) which mandates District Assemblies to formulate and execute plans, programs, and strategies for the effective mobilization of resources necessary for the overall development of Districts.

\subsection{Corporate Social Responsibility}

Corporate social responsibility programs is one of the arenas through which companies share mining benefits directly with communities in the periphery of mining operations. It is also one area the Assemblies can influence development distribution in the Districts such as social infrastructure and other benefits. Therefore, the study sought to find out whether there are formal processes or collaborations between the Assemblies and the companies on the selection of CSR projects. The study discovered that District Assemblies are not able to influence CSRs of mining companies. CSR projects carried out by mining companies are done often without inputs from the final beneficiaries. A wider consultation with communities in relation to implementation of CSR projects by mining companies would not only improve corporate-community relationship, but as well help in identifying problems or projects that need to be prioritized. Further, the study observed that social interventions by mining companies go only to communities within the immediate catchment areas. Communities located within the District but outside of catchment areas receive no consideration. Coordination by mining companies at the very least with the District Assemblies can help avoid the alleged discrimination in the sharing of mineral rents.

\subsubsection{Distribution of Mining Benefits}

Similar to the CSR issue discussed earlier, the study observed a phenomenon in the communities known as the 'home and away' practice. It describes the situation where opportunities such as scholarships and job opportunities extended to communities by mining companies are given out to people from distant or adjourning communities instead of indigenes or families directly affected by mining operations. Their concern had to do with claims that some community leaders such as traditional rulers, Assembly members and some officials in the mining companies distribute scholarships and job opportunities to not community members, but to those they consider as 'outsiders'. Most people in the study communities had no information about mining revenues received by the District Assemblies in the first place. The only thing known to most of them is the scholarships provided by mining 
companies to students in the communities while others had never heard of the Minerals Development Fund (MDF), much less its disbursement modalities.

In general, the majority of respondents did not believe their communities were benefiting from the presence of mines in their communities. Instead, they feel that staff of the Assemblies serve their own interest and not that of the communities and therefore not much is being done by the Assemblies to ensure that the larger communities benefit from mining operations, since there is nothing to show for the mining revenues the Assemblies receive. An open, transparent and merit-based system of awarding scholarships and employment opportunities by mining companies in their areas of operations will reduce the suspicions of collusion in the selection process and further make the investment impactful to the beneficiaries and community at large.

The study gathered further that revenues generated from mining activities by the Districts are rather used in putting up office complexes or renovating old ones, instead of investing in creating alternative livelihood opportunities for areas heavily impacted by mining operations. They contend that financing local government office complexes and other office related expenses through mining revenues is not prudent since that is the responsibility of the central government. The general impression is that mining has not brought any additional benefits to the communities, since mining benefits are not equitably and prudently shared and utilized. Although the companies carry out CSR projects and other interventions to mitigate mining impacts on traditional livelihoods, the development of the communities is the responsibility of local government and not that of the companies. Since the companies pay the appropriate taxes and royalties to the Government, it is the responsibility of the local government to use those funds for community's development.

\section{Discussion}

After nearly four decades of sustained reforms in the mining sector in Ghana, the question remains, has the mining sector proved to be an effective vehicle for poverty alleviation and sustained national development? Thus, in seeking to maximize the socio-economic benefits that accrue from mining, has Ghana succeeded in creating a framework for expanding and sustaining any such gains made? There is much disagreement about the importance of the contribution of mining to Ghana's national economic development. The debate is even more intense with respect to the contribution of mining activities to poverty reduction efforts, particularly in local communities directly impacted by mining activities where poverty is pervasive. Since the commencement of major reforms in the mining sector decades ago, several legislative frameworks and policies have been enacted and designed respectively to cater for the development needs of mining host communities. This is to among other things; mitigate the adverse impacts mineral exploitation exacts on traditional livelihood foundations. One of such recent legislative pieces designed to address development gaps and enhance equitable distribution of mineral rents in mining affected communities is the Minerals Development Fund Act, 2016 (Act 912) ${ }^{1}$.

However, despite the positive intentions of the Act, if local capacity gaps on sustainable economic development planning are not strengthened, the Act may not realize what it was originally envisioned. One of the initial steps required is the need to enhance participatory grassroots governance. This will give communities a voice in relation to the use of mineral resources and also exact accountability among local duty bearers. The Local Government Act, 1993 (Act 462) allows the topmost local government official to be appointed by the President at the national level. This in effect makes the District Chief Executive, who is the political head accountable to the appointing authority, thus the President and not the people he/she presides over.

As a result of this political arrangement, decisions arrived at on royalties and their utilization for purposes of community development are not binding on the local political head (DCE). The current political arrangement in essence, weakens the pillars of democratic accountability as communities cannot hold their local heads responsible over the utilization of mineral resources except the appointing authority, the President. Work done by Brunnschweiler and Bulte, (2008) suggest that mineral wealth, when properly accounted for and distributed, facilitates positive institutional development and impacts positively on the economy. It is argued therefore that the current decentralized political system does not only discourage participatory governance but also weakens local institutional development. It is therefore suggested that the Local Government Act, 1993 (Act 462) be amended to allow DCEs to be elected directly by the people they preside over so that they (DCEs) can be held to account directly by the people.

Government policy creates clear incentives and disincentives related to cost - either directly through a tax or indirectly with environmental guidelines. Corporations also take into account local administrative efficiencies, or lack of thereof, when considering investment in a new project (Poelzer and Jagers, 2021). Thus, the inherent weakness in political institutions related to the mining industry in most mineral-rich developing countries tends to favor corporate interests over socioeconomic and environmental impacts and concerns. The study discovered signs

\footnotetext{
${ }^{1}$ The MDF was established by Act 912 and passed by Parliament in March 2016 to provide a more reliant and predictable source of funding development initiatives in mining communities. The mandate of the Fund is to provide "financial resources for the direct benefit of mining communities, and a holder of an interest in land within mining communities and an institution responsible for the development of mining in Ghana. Source: PREAMBLE OF MDF ACT - Minerals Development Fund.
} 
of lack of capacity to create the required linkage between mining and the rest of the local economy and rather than the willingness to do so. This has led to hopelessness among people living in mining affected towns with respect to whether mining can provide the requisite opportunities in terms of direct employment and other downwards linkages associated with the extractive industry. The consequence is that negative externalities occur because private mining entities are faced with a "moral hazard" problem. Without the intervention of other affected parties (at the government and community levels), private miners have little incentive to limit their exposure to risks because they do not bear the full cost of such risks (Adu-Baffour et al, 2021).

The Minerals Development Fund Act, 2016 (Act 912) governs the mining sector in Ghana. It seeks to, among other things, enhance the interests of the general population by regulating natural assets including mineral resources, and ensures that the government receives its due rents and taxes from the exploitation of mineral resources in the country. However, this study has shown that mining affected communities are yet to derive significant benefits from their mineral resources despite decades of mineral exploitation. Development planning in these mineral-endowed Districts is hinged upon what is received in terms of revenues from the extractives. However, due to capacity gaps and inefficiencies, local governments are not able to rake in the required revenues for development purposes. Indeed, past experience indicates that most governments in mineral-rich developing countries lack the capacity to be effective and, above all, efficient in exploring for, developing and exploiting their natural resources and equally so in satisfying the related development risk capital needs, (Lilford and Guj, 2020).

\subsection{Conclusion}

Overall, this study showed the weakening efforts of sub-national level government structures in incorporating extractive issues in economic development planning in mineral-endowed Districts. While Ghana's mining boom has resulted in substantial revenues at the national level and increased national GDP as well as a leading destination for foreign direct investment in recent decades, mining affected communities are not profiting from this boom. Instead, livelihood foundations of local communities continue to be eroded with lost income opportunities, health hazards and social and cultural alienation. Local level development planning can address these negative externalities by ensuring a backflow of mineral revenues to local people to help develop alternative income strategies while making space for participatory decisions on compensation schemes.

The study contributes to the field by unearthing the gaps in decentralized government institutions in economic development planning with integration of extractive issues. The interviews were centered on local government institutions, civil society organizations, community based organizations, as well as youth and women groups. Future research in this area should incorporate the views of the corporate entities to understand the obstacles and levels of engagements with decentralized government structures and local populations on the sharing of mining benefits in their operational enclaves. This will provide a holistic and complete understanding of the dynamics in local economic development planning processes and the effects of mining investments on local livelihoods and sustainable economic development.

\section{References}

Addison, T. Boly, A. Mveyange, A. (2016). Mining and Economic Development: Did China's WTO Accession Affect African Local Economic Development? Policy Research Working Paper; No. (7906). Retrieved from https://openknowledge.worldbank.org/handle/10986/25805.

Adhikari S: R (2016), Methods of Measuring Externalities. In: Economics of Urban Externalities. Springer Briefs in Economics. Springer, Singapore. http://doi.org/10.1007/978-981-10-0545-9_2

Adu-Baffour, F., Daum, T., \& Birner, R. (2021). Governance challenges of small-scale gold mining in Ghana: Insights from a process net-map study. Land Use Policy, 102, 105271.

Ahwoi, K. (2010). Rethinking decentralization and local government in Ghana proposals for amendment. Retrieved from Rethinking Decentralization and Local Government in Ghana proposals for Amendment (africaportal.org).

Antoci, A., Russu, P., \& Ticci, E. (2019). Mining and Local Economies: Dilemma between Environmental Protection and Job Security. Sustainability (2071-1050), 11(22)

Aryee, B. N. (2001). Ghana's Mining Sector: It's Contribution to the National Economy. Resources Policy, 27(2), 61-75. DOI: 10.1016/S0301-4207(00)00042-8

Azumah FD, Baah E, Nachinaab JO. Causes and Effects of Illegal Gold Mining (Galamsey) Activities on School Dropout and Residents at the Tutuka Central Circuit in Obuasi Municipality in Ashanti Region, Ghana. Journal of Education. 2021; 201(3):162-173. Doi: 10.1177/0022057420905109

Brunnschweiler, C. N., \& Bulte, E. H. (2008). The resource curse revisited and revised. A tale of paradoxes and red herrings. Journal of environmental economics and management, 55(3), 248-264.

Campbell, B. (Ed.). (2009). Mining in Africa: Regulation and development. IDRC. DOI: 10.1016/S03014207(00)00042-8

Chuhan-Pole, Punam; Dabalen, Andrew L.; Land, Bryan Christopher. (2017). Mining in Africa: Are Local 
Communities Better Off? Africa Development Forum; Washington, DC: World Bank. Retrieved from https://openknowledge.worldbank.org.

De Souza, S. V., Dollery, B., \& Blackwell, B. (2018). An empirical analysis of mining costs and mining royalties in Queensland local government. Energy Economics, 74, 656-662.

Hajkowicz, S. A., Heyenga, S., \& Moffat, K. (2011). The relationship between mining and socio-economic wellbeing in Australia's regions. Resources Policy, 36(1), 30-38.

Hammond, D. S., Gond, V., De Thoisy, B., Forget, P. M., \& DeDijn, B. P. (2007). Causes and consequences of a tropical forest gold rush in the Guiana Shield, South America. Journal of the Human Environment 36(8):66170.DOI:10.1579/0044-7447(2007)36[661: CACOAT] 2.0.CO; 2

Karakaya, E., \& Nuur, C. (2018). Social sciences and the mining sector: some insights into recent research trends. Resources Policy, 58, 257-267.

Kesler, S. E., \& Simon, A. C. (2015). Mineral resources, economics and the environment. Cambridge University Press. P. 261-262: doi: 10.1515/logos-2016-0026

Knutsen, C. H., Kotsadam, A., Olsen, E. H., \& Wig, T. (2017). Mining and local corruption in Africa. American Journal of Political Science, 61(2), 320-334.

Lilford, E., \& Guj, P. (2020). Mining Taxation: Reconciling the Interests of Government and Industry (Vol. 18). Springer Nature.

Lilford, E., \& Guj, P. (2021). Components of a Mining Taxation Package. In Mining Taxation (pp. 29-41). Springer, Cham.

Loayza, N., \& Rigolini, J. (2016). The local impact of mining on poverty and inequality: evidence from the commodity boom in Peru. World development, 84, 219-234.

Lujala, P., \& Narh, J. (2020). Ghana's Minerals Development Fund Act: Addressing the needs of mining communities. Journal of Energy \& Natural Resources Law, 38(2), 183-200.

McQuilken, J., \& Hilson, G. (2016). Artisanal and Small-scale Gold Mining in Ghana: Evidence to inform an 'action Dialogue'. International Institute for Environment and Development: DOI: 10.13140/RG.2.2.36435.99368

Poelzer, G., Linde, S., Jagers, S. C., \& Matti, S. (2021). Digging in the dark: reviewing international literature to address impending policy challenges for Swedish and Finnish mining. Mineral Economics, 34(2), 225-238.

Population and Housing Census, District Analytical Report (2014): Prestea-Huni Valley District. Access from. https://www2.statsghana.gov.gh/docfiles/2010_District_Report/Western/Prestea\%20Huni-Valley.pdf

Population and Housing Census, District Analytical Report (2014): Wassa East District. Access from. https://www2.statsghana.gov.gh/docfiles/2010_District_Report/Western/Wassa\%20East.pdf

Robinson, R. L., \& Mackenzie, B. W. (1987). Economic Comparison of Mineral Exploration and Acquisition Strategies to Obtain Ore Reserves. In APCOM 87, Proceedings of the Twentieth International Symposium on the Application of Computers and Mathematics in the Mineral Industry (Vol. 3, pp. 297-300).

Ross, M.L (2015). What have we learnt about the resource curse? Annual Review of Political Science. Vol. 18:239$259 \mathrm{https} / / /$ doi.org/10.1146/annurev-polisci-052213-040359

Schueler, V., Kuemmerle, T. \& Schröder, H. Impacts of Surface Gold Mining on Land Use Systems in Western Ghana. AMBIO 40, 528-539 (2011). https://doi.org/10.1007/s13280-011-0141-9

Sexton, R. (2020). Unpacking the local resource curse: How externalities and governance shape social conflict. Journal of Conflict Resolution, 64(4), 640-673.

Tetreault, D. (2020). The new extractivism in Mexico: Rent redistribution and resistance to mining and petroleum activities. World Development, 126, 104714.

Yelpaala, K., \& Ali, S. H. (2005). Multiple scales of diamond mining in Akwatia, Ghana: addressing environmental and human development impact. Resources Policy, 30(3), 145-155. DOI: 10.1016/j.resourpol.2005.08.001 